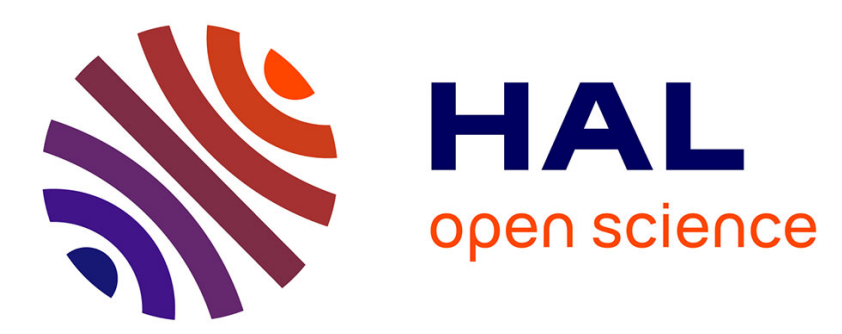

\title{
Advance of WISDOM GPR Antenna for ExoMars 2018 Mission
}

Wolf-Stefan Benedix, Dirk Plettemeier, André Zanoni, Fabian Preller, Valérie Ciarletti

\section{> To cite this version:}

Wolf-Stefan Benedix, Dirk Plettemeier, André Zanoni, Fabian Preller, Valérie Ciarletti. Advance of WISDOM GPR Antenna for ExoMars 2018 Mission. WiSEE 2013, IEEE International Conference on Wireless for Space and Extreme Environments, Nov 2013, Baltimore, United States. hal-00908460

\section{HAL Id: hal-00908460 https://hal.science/hal-00908460}

Submitted on 23 Nov 2013

HAL is a multi-disciplinary open access archive for the deposit and dissemination of scientific research documents, whether they are published or not. The documents may come from teaching and research institutions in France or abroad, or from public or private research centers.
L'archive ouverte pluridisciplinaire HAL, est destinée au dépôt et à la diffusion de documents scientifiques de niveau recherche, publiés ou non, émanant des établissements d'enseignement et de recherche français ou étrangers, des laboratoires publics ou privés. 


\title{
Advance of WISDOM GPR Antenna for ExoMars 2018 Mission
}

\author{
Wolf-Stefan Benedix*, Dirk Plettemeier*, André Zanoni ${ }^{\dagger}$, Fabian Preller ${ }^{\ddagger}$ and Valerie Ciarletti ${ }^{\S}$ \\ ${ }^{*}$ Dresden University of Technology \\ Department of Electrical Engineering and Information Technology \\ Chair for RF; 01062 Dresden, Germany \\ Email: \{wolf-stefan.benedix, dirk.plettemeier\}@tu-dresden.de \\ ${ }^{\dagger}$ Dresden University of Technology \\ Faculty of Mechanical Science and Engineering \\ Chair for Space Systems; 01062 Dresden, Germany \\ †Invent GmbH, 38112 Braunschweig, Germany \\ ${ }^{\S}$ Universite Versailles St-Quentin; CNRS/INSU; LATMOS-IPSL, France
}

\begin{abstract}
The Experiment "Water Ice and Subsurface Deposit Observations on Mars" (WISDOM) is a Ground Penetrating Radar (GPR) selected to be part of the Pasteur payload on board the rover of European Space Agency's (ESA) ExoMars 2018 mission. The GPR antenna system described in this paper is the consequent progression of former developments [1, 2] incorporating changed requirements and further optimizations. Main constraints are the mass, the temperature range as well as the ultra-wide band demand. The antenna requirements which are to fulfill for this very specific GPR application are described here. Furthermore, it is given an overview about the lightweight design and its realization. Simulated and measured antenna performance is compared in this paper.
\end{abstract}

\section{INTRODUCTION}

One of the most important goal of the ExoMars2018 mission describes the quest of present or past life forms. One crucial instrument represents the ground penetrating radar experiment WISDOM, with which assistance the geology of the near soil layers will be investigated and furthermore the selection process of suitable drill sites are supported.

This instrument itself has been designed to characterize the shallow subsurface structure of Mars [3]. The radar is a gated step frequency system covering a frequency range from $0.5 \mathrm{GHz}$ to $3 \mathrm{GHz}$ [4].

The antenna actually consists of two antennas sending and receiving two orthogonal polarizations each.

\section{ANTENNA REQUIREMENTS}

The demands result from the application as ground penetrating radar antenna on the one hand and on the other hand from the environmental conditions of the mission. The latter vary over the different phases (ground phase, transportation phase, Mars surface) and show particularly high loads during launch (mechanical loads) and during the surface mission on Mars (thermal loads).

Table I shows the electrical requirements, which arise from intended use while Table II lists the demands from the most critical environmental constraints of the mission.
TABLE I: List of electrical requirements of the WISDOM antenna

\begin{tabular}{lcc}
\hline \multicolumn{1}{c}{ Requirement } & Value \\
\cline { 1 - 1 } Frequency bandwidth & & $0.5 \ldots 3.0 \mathrm{GHz}=2.5 \mathrm{GHz}$ \\
Polarization $(\mathrm{Tx}, \mathrm{Rx})$ & linear, XX $-\mathrm{XY}-\mathrm{YX}-\mathrm{YY}$ \\
Matching $\left(S_{11}\right)$ & $\leq-10 \mathrm{~dB}$ \\
Radiation pattern & homogenous main lobe \\
Beam width & $>20^{\circ}$, H-plane $>$ E-plane \\
Gain function & & smooth, increasing with frequency \\
Antenna cross talk & $<-15 \mathrm{~dB}$ (for all polarizations) \\
Pointing error & $<5^{\circ}$ (for all frequencies) \\
Radiation coupling to rover & as low as possible \\
\hline
\end{tabular}

TABLE II: List of mechanical and thermal requirements of the WISDOM antenna

\begin{tabular}{lcc}
\hline \multicolumn{1}{c}{ Requirement } & Value \\
${$\cline { 1 - 1 }$} }$ & $140 \mathrm{~Hz}$ \\
Mass budget & $400 \mathrm{~g}$ \\
Envelope & $200 \mathrm{~mm} \times 410 \mathrm{~mm} \times 180 \mathrm{~mm}$ \\
Temperature range (non-op) & $-120^{\circ} \mathrm{C}$ to $+115^{\circ} \mathrm{C}$ \\
Temperature range (operating) & $-90^{\circ} \mathrm{C}$ to $+115^{\circ} \mathrm{C}$ \\
\hline
\end{tabular}

\section{ELECTRICAL PROPERTIES}

\section{A. Divider}

The antenna design was developed based on a Tapered Slot Antenna with exponential taper (Vivaldi). This kind of antenna fulfills several requirements very well and possesses a comparatively low mass. The construction as a two element array per polarization plane yields in a reduced height of the antenna model. However, this setup needs a broad band power divider with low insertion losses. Several concepts have been evaluated. One of the promising drafts used a transformation divider. But due to the large operating temperature range the use of a divider based on the transformation principle might be critical, since the influence on the magnetic materials is not known. Therefore the so called Wilkinson power divider has been employed. In the former design a five-step variation 


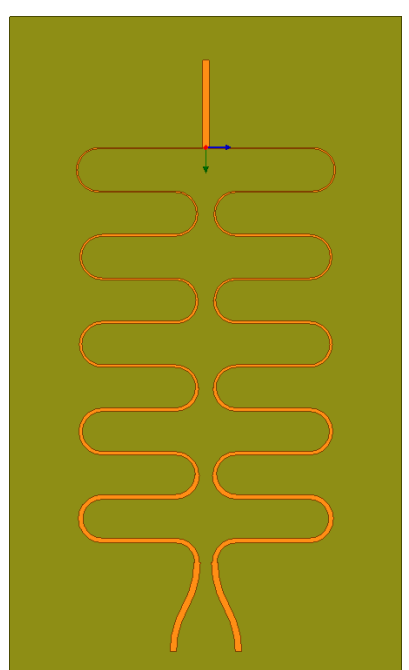

(a)

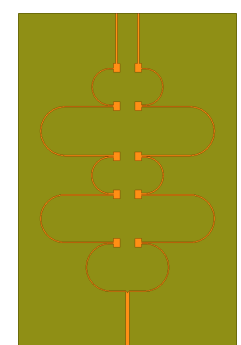

(b)

Fig. 1: Comparison of the a) former and b) recent version of the Wilkinson divider (not to scale)

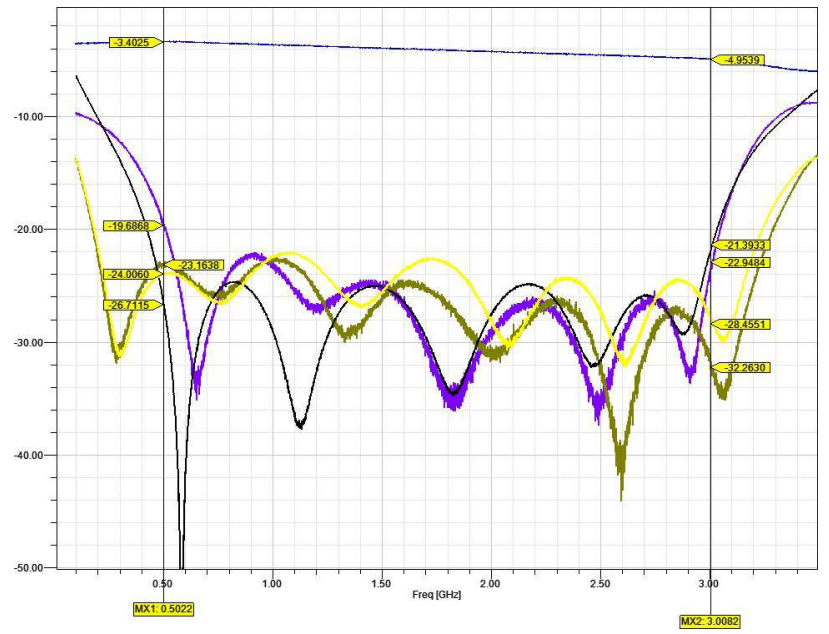

Fig. 2: Measurement results of the former Wilkinson divider:

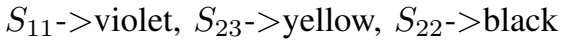

was developed. But this design occupies a space of about $38 \mathrm{~mm} \times 25 \mathrm{~mm}$ and its integration was a demanding step during the assembly of the antenna. For this reason, the divider is minimized $21 \mathrm{~mm} \times 16 \mathrm{~mm}$ at a reasonable cost of performance changes [5]. Figure 1 shows both the old and new power divider design. The diagram of Figure 2 represents measurement results of the former divider. One can see that over the full frequency range the matching of all ports as well as the isolation are better than $-20 \mathrm{~dB}$, while the insertion loss is lower than $2 \mathrm{~dB}$. In comparison the values of the simulation results of the new design in Figure 3 ( $S_{11}$ only) do not reach its predecessor.

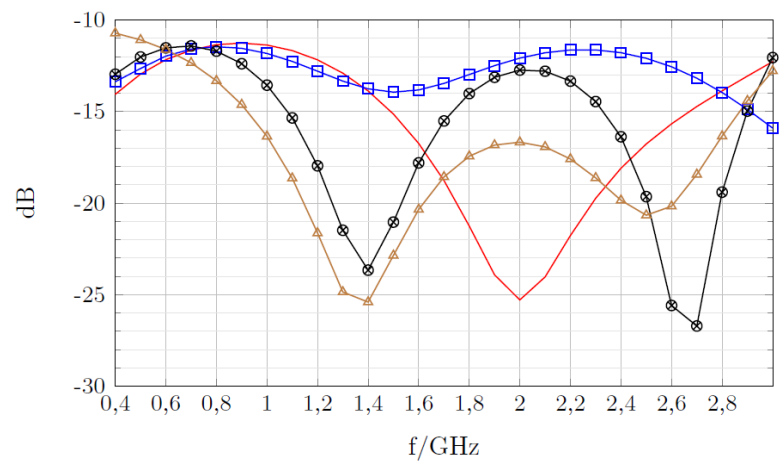

Fig. 3: Measurement results of the recent Wilkinson divider: $S_{11}->$ brown, other colors represent different divider designs

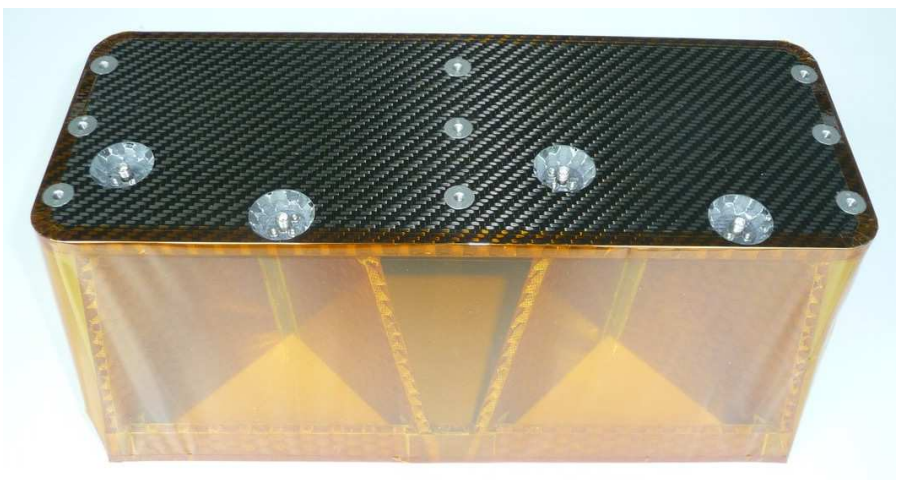

Fig. 4: Intermediate design study with a base plate made of a sandwich of aluminum honey comb between CFRP sheets

\section{B. Optimization of Vivaldi taper}

This section will be described in the full paper, since the optimization is not completed yet.

\section{MechanicAl PROPERTIES}

The most limiting factor of the antenna design constitutes the mass budget of $400 \mathrm{~g}$ maximum. From a design change of the antenna mount, new requirements for the antenna base plates revealed. With the redesign the both separate antenna are combined on a single base plate. This eventually leads to a mass reduction in several points:

- less screws (from 16 to 9)

- less structural side elements

- narrow base plate

On the other hand the core material of the base plate have to be changed from glass fiber reinforced plastic (GFRP) to aluminum to withstand the mechanical loads. Figure 4 shows an intermediate design study where the sheets of the base plate sandwich structure still made of carbon fiber reinforced plastic (CFRP).

The structure reinforcing elements at the bottom of the antenna are realized as its predecessor by honey comb structure on the basis of a single GFRP material.

By reducing the thickness of the copper layer of $18 \mu \mathrm{m}$ to $5 \mu \mathrm{m}$, the accelerated masses are reduced to the extent that 


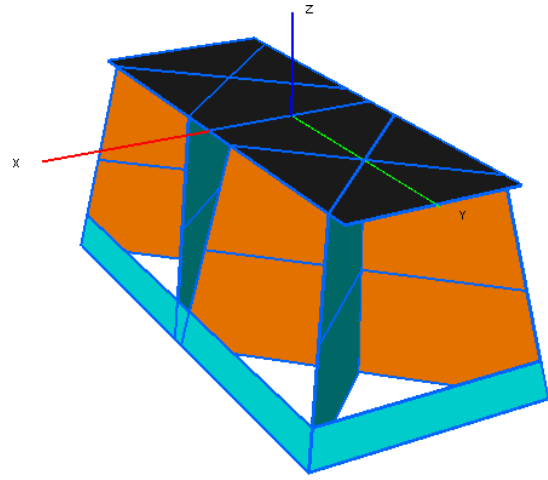

Fig. 5: Geometrical mathematical model of the WISDOM antenna

the honeycomb structure with thinner materials withstands the mechanical loads with a safety margin.

\section{THERMAL PROPERTIES}

\section{A. Thermal loads}

As one of the external survey instruments the WISDOM antenna has to withstand a large temperature range between $-120^{\circ} \mathrm{C}$ and $+115^{\circ} \mathrm{C}$. The first bound derives from the lowest conceivable temperature on the Mars surface at the expected position. The latter is due to a sterilization requirement with a dry heat microbial reduction. The FEM calculation show, that large temperature changes (from $20^{\circ} \mathrm{C}$ down to $-120^{\circ}$ ) do not reveal critical stresses on the material.

\section{B. Thermal analysis}

The thermal influences of the antenna have been analyzed with a thermal mathematical model of the antenna. The geometrical mathematical model of the intermediate design study is shown in Figure 5.

\section{CONCLUSION - OUtLOOK}

In the final paper we will present measurements of the new divider as well as radiation pattern and gain function of the antenna system. Further the results of the thermal analysis are shown. All points will be discussed in detail.

\section{ACKNOWLEDGMENT}

WISDOM development and this research were supported by funding from the French space agency CNES and from the German space agency DLR.

\section{REFERENCES}

[1] D. Plettemeier, C. Corbel, S.-E. Hamran, V. Ciarletti, W.S. Benedix, S. Balling, and S. Linke, "Ultra light-weight antenna system for full polarimetric GPR applications," in EUROCON 2009, EUROCON '09. IEEE, May 2009, pp. $1557-1564$.

[2] D. Plettemeier, V. Ciarletti, S.-E. Hamran, C. Corbel, P. Cais, W.-S. Benedix, K. Wolf, S. Linke, and S. Roddecke, "Full polarimetric GPR antenna system aboard the
ExoMars rover," in Radar Conference, 2009 IEEE, May 2009, pp. 1-6.

[3] V. Ciarletti, C. Corbel, D. Plettemeier, P. Cais, S. Clifford, and S.-E. Hamran, "Wisdom gpr designed for shallow and high-resolution sounding of the martian subsurface," Proceedings of the IEEE, vol. 99, no. 5, pp. $824-836$, may 2011.

[4] M. Oyan, S. Hamran, L. Hanssen, T. Berger, and D. Plettemeier, "Ultrawideband gated step frequency groundpenetrating radar," Geoscience and Remote Sensing, IEEE Transactions on, vol. 50, no. 1, pp. $212-220$, jan. 2012.

[5] Franz Schroeder, "Entwicklung einer Teilerstruktur," Jan. 2013, student thesis. 